Original Article

\title{
EVALUATION OF ANTIBIOTIC EFFICACY AND PRESCRIBING PATTERN IN SKIN AND SKIN STRUCTURE INFECTIONS AT A TERTIARY CARE TEACHING HOSPITAL
}

\author{
NAZISH FATHIMA*, SONIYA M., TANI ELSA THOMAS, TEENA ELSA TIGI \\ Department of Pharmacy Practice, Bapuji Pharmacy College, Rajiv Gandhi University of Health Sciences, Davangere, 577004, India \\ *Email: naazfathima93@gmail.com
}

Received: 20 Apr 2021, Revised and Accepted: 12 Jun 2021

ABSTRACT

Objective: This study was carried out to evaluate the efficacy and prescribing pattern of antibiotics in the skin and skin structure infections (SSTIs) at tertiary care teaching hospital.

Methods: In this prospective observational study, an attempt was made to evaluate the efficacy and prescribing pattern of antibiotics. Subjects were selected according to the inclusion and exclusion criteria and patient case sheets were analyzed for patient demographic details, results of physical examination and laboratory parameters, and prescription pattern.

Results: Cellulitis was the most common skin and skin structure infection among the subjects, followed by an ulcer. Few patients showed discomforts such as pain, swelling, and purulent discharge. Surgical procedure has been done in 76 patients. Out of 99 patients, 11 patients showed a prolonged length of stay (LOS) ( $\geq 16 \mathrm{~d}$ ), which is an indication of the poor efficacy of antibiotics. Intravenous to oral antibiotic therapy switch was seen in 47 patients, which indicates that the patient's condition was improved. The mean length of hospital stay was $8.79 \mathrm{~d}$. The majority of patients have been discharged within $15 \mathrm{~d}$. Cephalosporins were the most frequently prescribed class of antibiotics in patients with skin and soft tissue infections. Metronidazole was the most frequently used antibiotic as monotherapy followed by cefuroxime. Piperacillin+Tazobactam was the most frequently used combination antibiotic. This study finds that the antibiotic treatment was efficacious in the majority of the patients.

Conclusion: This study finds that the antibiotic treatment was efficacious in the majority of the patients.

Keywords: SSTI, LOS, VAS, ABSSI, cSSTI

(C) 2021 The Authors. Published by Innovare Academic Sciences Pvt Ltd. This is an open access article under the CC BY license (https://creativecommons.org/licenses/by/4.0/) DOI: https://dx.doi.org/10.22159/ijpps.2021v13i8.41851. Journal homepage: https://innovareacademics.in/journals/index.php/ijpps.

\section{INTRODUCTION}

The objective of this study was to evaluate the efficacy and prescribing pattern of antibiotics in the skin and skin structure infections at a tertiary care teaching hospital. Skin and soft tissue infections (SSTIs), also known as skin and skin structure infections, include a group of infections that differ in their clinical presentations and degrees of severity [1]

The majority of skin and soft tissue infections are caused by bacteria and are hence referred to as acute bacterial skin and skin structure infections (ABSSSIs). Some cases are caused by viruses-most notably, the varicella-zoster virus (VZV). Similarities in signs and symptoms and difficulty in the ability to identify the causative organisms promptly make the diagnosis and treatment of skin and soft tissue infections challenging in the initial stages. Therefore, careful assessment of risk factors and degree of severity, as well as obtaining a detailed medical history and performing a physical examination are required to appropriately diagnose and manage a patient presenting with a skin and soft tissue infection. Antimicrobial regimens are often selected empirically based on host characteristics, most likely pathogens, and local susceptibility patterns, with streamlining according to microbiology culture and sensitivity if the causative organisms are isolated [1].

Skin and soft tissue infections may involve any or all layers of the skin (epidermis, dermis), subcutaneous fat, fascia, or muscle [2] Skin and soft tissue infections are classified as complicated (cSSSIs) when the infection has spread to the deeper tissues, surgical intervention is required, or the patient has a comorbid condition (e. g. diabetes mellitus) that complicates response to treatment [3]. Complicated skin and soft tissue infections include necrotizing fasciitis, myositis, and gangrene. Uncomplicated skin and skin structure infections may result from minor skin abrasions or even insect bites and include cellulitis, erysipelas, carbuncles, and impetigo [4]

According to the 2011 National Statistics of the Healthcare Cost and Utilization Project, 3.4 million emergency department visits were contributed by skin and soft tissue infections, or $2.6 \%$ of all emergency department visits, with $13.9 \%$ of visits resulting in hospitalization [3]. Treating predisposing conditions such as obesity, edema, venous insufficiency, and eczema reduces the risk of recurrent infections [1].

\section{MATERIALS AND METHODS}

Patients having skin and skin structure infections given with at least one antibiotic were included in the study. Patients who were not willing to participate in the study; who had underlying diseases like HIV, leprosy, TB, psoriasis, and outpatients were excluded. Consent to participate in the study was obtained from patients prior to the study. Permission to conduct the study was obtained from Institutional Ethics Committee (BPC/IEC/65/2019-20). Subjects were selected as per the inclusion criteria and patient case sheets were analyzed for patient demographic details, results of physical examination and laboratory parameters and prescription pattern. Evaluation of efficacy was done using the following parameters: wound healing status and presence/absence of pain using visual analogue pain scale, swelling, purulent discharge, intravenous to oral switch, surgical interventions, and length of stay. The prescription pattern of antibiotics in the skin and soft tissue infections was studied. The data collected were analyzed for the following parameters: Efficacy and Prescribing pattern. 


\section{RESULTS AND DISCUSSION}

Table 1: Distribution of subjects based on gender

\begin{tabular}{lll}
\hline Gender & No. of subjects (N=99) & Percentage (\%) \\
\hline Male & 64 & 64.64 \\
Female & 35 & 35.35 \\
Total & 99 & 99.99 \\
\hline
\end{tabular}

Table 2: Distribution of subjects based on age

\begin{tabular}{|c|c|c|c|c|c|c|c|c|}
\hline \multirow{2}{*}{$\begin{array}{l}\text { Age (in } \\
\text { years) }\end{array}$} & \multicolumn{2}{|l|}{ 18-38 } & \multicolumn{2}{|l|}{ 39-59 } & \multicolumn{2}{|l|}{$60-80$} & \multicolumn{2}{|l|}{$>80$} \\
\hline & $\begin{array}{l}\text { No. of } \\
\text { patients }\end{array}$ & Percentage & $\begin{array}{l}\text { No. of } \\
\text { patients }\end{array}$ & Percentage & $\begin{array}{l}\text { No. of } \\
\text { patients }\end{array}$ & Percentage & $\begin{array}{l}\text { No. of } \\
\text { patients }\end{array}$ & Percentage \\
\hline Male & 14 & 14.14 & 22 & 22.22 & 25 & 25.25 & 3 & 3.03 \\
\hline Female & 13 & 13.13 & 11 & 11.11 & 10 & 10.1 & 1 & 1.01 \\
\hline Total & 27 & 27.27 & 33 & 33.33 & 35 & 35.35 & 4 & 4.04 \\
\hline
\end{tabular}

Table 3: Types of skin and skin structure infections

\begin{tabular}{|c|c|c|c|c|c|c|}
\hline \multirow[t]{2}{*}{ Type of SSTI } & \multicolumn{4}{|c|}{ Age grouping } & \multicolumn{2}{|l|}{ Total } \\
\hline & 18-38 & $39-59$ & $60-80$ & $>80$ & No. of cases $(\mathrm{N}=99)$ & Percentage (\%) \\
\hline Cellulitis & 8 & 12 & 13 & 4 & 37 & 37.37 \\
\hline Ulcer & 1 & 13 & 12 & 0 & 26 & 26.26 \\
\hline Abscess & 11 & 5 & 6 & 0 & 22 & 22.22 \\
\hline Wound & 2 & 2 & 3 & 0 & 7 & 7.07 \\
\hline Surgical site infection & 3 & 1 & 1 & 0 & 5 & 5.05 \\
\hline Necrotizing fasciitis & 3 & 0 & 0 & & 3 & 3.03 \\
\hline Furunculitis & 0 & 0 & 1 & 0 & 1 & 1.01 \\
\hline
\end{tabular}

Table 4: Efficacy evaluation of antibiotics in skin and soft tissue infections

\begin{tabular}{|c|c|c|}
\hline Parameters & Status & Percentage (\%) \\
\hline \multirow[t]{3}{*}{ Wound Healing } & Healed-13 & 13.13 \\
\hline & Healing-80 & 80.80 \\
\hline & Not healed-6 & 6.06 \\
\hline \multirow[t]{3}{*}{ Pain } & Absent-21 & 21.21 \\
\hline & Reduced-61 & 61.61 \\
\hline & Present-17 & 17.17 \\
\hline \multirow[t]{3}{*}{ Swelling } & Absent-48 & 48.48 \\
\hline & Reduced-42 & 42.42 \\
\hline & Present-9 & 9.09 \\
\hline \multirow[t]{2}{*}{ Purulent discharge } & Present-19 & 19.19 \\
\hline & Absent-80 & 80.80 \\
\hline \multirow[t]{2}{*}{ Intravenous to oral switch } & Yes-47 & 47.47 \\
\hline & No-52 & 52.52 \\
\hline \multirow{2}{*}{ Surgical intervention } & Yes-76 & 76.76 \\
\hline & No-23 & 23.23 \\
\hline \multirow[t]{5}{*}{ Length of stay (d) } & $0-15: 88$ & 88.88 \\
\hline & 16-30: 10 & 10.10 \\
\hline & $31-45: 1$ & 1.01 \\
\hline & 46-60: 0 & 0 \\
\hline & 61-75: 0 & 0 \\
\hline
\end{tabular}

Table 5: Class of antibiotics prescribed in the skin and soft tissue infections

\begin{tabular}{lll}
\hline Class of antibiotics & $\begin{array}{l}\text { No. of prescriptions with the given class of } \\
\text { antibiotics } \mathbf{N = 9 9 )}\end{array}$ & $\begin{array}{l}\text { Percentage of a given class of antibiotic in total no. of } \\
\text { prescriptions }\end{array}$ \\
\hline Cephalosporins & 85 & 85.85 \\
Penicillin & 51 & 51.51 \\
Nitroimidazole & 41 & 41.41 \\
Fluoroquinolones & 18 & 18.18 \\
Carbapenem & 15 & 15.15 \\
Lincomycin & 5 & 5.05 \\
Aminoglycosides & 5 & 5.05 \\
Oxazolidinone & 4 & 4.04 \\
Macrolide & 1 & 1.01 \\
\hline
\end{tabular}


Table 6: Antibiotics prescribed as monotherapy

\begin{tabular}{|c|c|c|}
\hline Antibiotics & No. of patients $(\mathrm{N}=99)$ & Percentage (\%) \\
\hline Metronidazole & 40 & 40.40 \\
\hline Cefuroxime & 39 & 39.39 \\
\hline Levofloxacin & 18 & 18.18 \\
\hline Cefpodoxime & 14 & 14.14 \\
\hline Meropenem & 11 & 11.11 \\
\hline Ceftriaxone & 6 & 6.06 \\
\hline Orpenem & 5 & 5.05 \\
\hline Clindamycin & 5 & 5.05 \\
\hline Faropenem & 5 & 5.05 \\
\hline Linezolid & 4 & 4.04 \\
\hline Amikacin & 4 & 4.04 \\
\hline Cefotaxime & 4 & 4.04 \\
\hline Ciprofloxacin & 2 & 2.02 \\
\hline Cefoperazone & 2 & 2.02 \\
\hline Doripenem & 1 & 1.01 \\
\hline Gentamicin & 1 & 1.01 \\
\hline Cephalexin & 1 & 1.01 \\
\hline Cefepime & 1 & 1.01 \\
\hline Azithromycin & 1 & 1.01 \\
\hline Ampicillin & 1 & 1.01 \\
\hline Cefixime & 1 & 1.01 \\
\hline
\end{tabular}

Table 7: Antibiotics prescribed as dual therapy

\begin{tabular}{lll}
\hline Dual therapy of antibiotics & No. of patients (N=99) & Percentage (\%) \\
\hline Piperacillin+tazobactam & 41 & 41.41 \\
Cefuroxime+sulbactam & 16 & 16.16 \\
Ceftriaxone+sulbactam & 15 & 15.15 \\
Cefpodoxime+dicloxacillin & 12 & 12.12 \\
Cefoperazone+sulbactam & 10 & 10.10 \\
Cefotaxime+sulbactam & 9 & 9.09 \\
Amoxicillin+dicloxacillin & 5 & 5.05 \\
Amoxicillin+clavulanic acid & 4 & 4.04 \\
Cefepime+tazobactam & 2 & 2.02 \\
Cefuroxime+tazobactam & 1 & 1.01 \\
Ceftriaxone+tazobactam & 1 & 1.01 \\
\hline
\end{tabular}

Table 8: Prescription pattern of antibiotics in the skin and soft tissue infections

\begin{tabular}{ll}
\hline Drug use indicators & Results \\
\hline Average no. of drug per encounter & 2.22 \\
Percentage of drugs prescribed by generic name & 63.63 \\
Percentage of encounters with an antibiotic prescribed & 100 \\
Percentage of encounters with an injection prescribed & 95.95 \\
Percentage of drugs prescribed from essential drugs list & 83.63 \\
\hline
\end{tabular}

Table 9: History of co-morbidities in study population

\begin{tabular}{lll}
\hline Comorbid condition & Frequency & Percentage (\%) \\
\hline Diabetes Mellitus & 30 & 30.30 \\
Hypertension & 22 & 22.22 \\
IHD & 4 & 4.04 \\
AKI & 2 & 2.02 \\
\hline
\end{tabular}

Table 10: Distribution based on body mass index

\begin{tabular}{lll}
\hline BMI & No. of patients (N= 99) & Percentage (\%) \\
\hline$<18.5$ & 2 & 2.02 \\
$18.5-24.9$ & 53 & 53.53 \\
$25-29.9$ & 33 & 33.33 \\
$\geq 30$ & 11 & 11.11 \\
Total & 99 & 99.99 \\
\hline
\end{tabular}

$<18.5$ : underweight, 18.5-24.9: normal, 25-29.9: overweight, $\geq 30$ : obese

The present study was conducted among the patients who got admitted to Shamanur Shivashankarappa Institute of Medical
Science and Research Centre for skin and soft tissue infections for a period of 6 mo. This was a prospective observational study. Our 
goals were to evaluate the efficacy and the prescribing pattern of antibiotics in the skin and soft tissue infections. During the study period, a total of 99 cases of SSTIs were monitored prospectively.

In our study, among the 99 individuals, 64 (64.64\%) were men and $35(35.35 \%)$ were women, who suffered from skin and skin structure infections. Brittany Cieri [5] et al. reported that $94.82 \%$ of the patients with skin and soft tissue infections were men. Out of 99 individuals, the majority of patients belong to the age group $60-80 \mathrm{y}$ (35.35\%). I. H. Jaaskelainen [6] et al. reported in their study that $62.93 \%$ of the subjects were above $60 \mathrm{y}$ old. Cellulitis $(37.37 \%)$ was found to be the most common skin and skin structure infection among the subjects followed by ulcer (26.26\%). This finding was similar to J. Garau [7] et al. and I. H. Jaaskelainen [8] et al. who also found cellulitis being the most common SSTI in their study. In contrast, Benjamin A Lipsky [9] et al. found SSI (32\%) being the most common SSTI and only $27 \%$ had cellulitis.

In this study, the antibiotic treatment was found to be efficacious in the majority of the patients. However, the wound was not healed in $6 \%$ of the patients and some of them have shown discomfort such as pain $(17.17 \%)$, swelling $(9.09 \%)$, and purulent discharge $(19.19 \%)$ despite the antibiotic treatment, which indicates the ineffectiveness of the antibiotics. The number of patients who went under surgical procedure was $76(76.76 \%)$. The mean length of hospital stay was $8.79 \mathrm{~d}$. The majority of patients have been discharged within $15 \mathrm{~d}$ $(88.88 \%)$. Out of 99 patients, $11(11.11 \%)$ patients had a prolonged length of stay $(\geq 16 \mathrm{~d})$, which is also an indication of poor efficacy of antibiotics. Intravenous to oral antibiotic therapy switch has been done in 47 patients, which means that these patients were showing improvement in their condition.

Cephalosporins were the most frequently prescribed class of antibiotics. As monotherapy, Metronidazole was used more frequently and Piperacillin-Tazobactam was the most prescribed antibiotic in dual therapy. Brittany Cieri [5] et al. reported that Vancomycin-Beta-lactam/beta-lactamase inhibitor was the most commonly prescribed antibiotics (24\%) in their study. In another study, Krishan Yadav [10] et al. reported that the most common oral agent used was cephalexin and the most common parenteral agent was cefazolin. The average number of drugs per encounter was 2.22. Overall, $95.95 \%$ of patients have been prescribed an injectable antibiotic, and $63.63 \%$ of drugs were prescribed by their generic name. $83.63 \%$ of prescribed drugs were from the essential drugs list. Likewise, Gebre Teklemariam Demoz [11] et al. reported that 52.3\% of patients had at least one oral and/or injectable antibiotic prescribed. The average number of prescribed antibiotics per patient was 2.01 in their study. They have also found that the majority $(97.6 \%)$ of antibiotics were prescribed by their generic name, and all prescribed antibiotics were from the National Essential Medicine List [11].

Diabetes, hypertension, ischemic heart disease, acute kidney injury, and obesity/overweight were the comorbidities present in the patients among which diabetes $(30.3 \%)$ was found to be the most frequent comorbid condition among skin and soft tissue infections patients. Similarly, Krishan Yadav [10] et al. and Brittany Cieri [5] et al. reported that the most frequent comorbidity was diabetes in their study. In our study, overweight/obesity (Body mass index $\geq 25$ ) was identified in $44.44 \%$. Also, Brittany Cieri [5] et al. found that $53.6 \%$ of the subjects were obese/extremely obese.

The risk of antibiotic failure increases in obese patients due to altered pharmacokinetics and pharmacodynamics of these drugs in them. Oral antibiotics may not reach the desired site of action due to the increased volume of distribution into adipose tissue, increased clearance, and inadequate antibiotic penetration in obese patients [2]. Studies have shown that patients with diabetes mellitus are at an increased risk for skin and soft tissue infections due to damage to lymphatic vessels and accompanying lower leg ulceration [5]. Those with diabetes mellitus were at an increased risk for failure in our study.

The limitations of this study were lack of culture results, missing data which was rectified by seeking help from medical staff and patients. The proposed sample size was not achieved, as the time available for data collection was less, due to the COVID-19 pandemic.

\section{CONCLUSION}

Antibiotic treatment remarkably represents the cornerstone for achieving optimal therapeutic outcomes in the management of skin and soft tissue infections. From the present study, it was found that Cephalosporins were the most frequently prescribed class of antibiotics. And Metronidazole was most frequently prescribed as monotherapy and most of the combinations consisted of Piperacillin-Tazobactam. Approximately $20 \%$ of them failed the treatment. Doing culture tests and treating the patient with the specific antibiotic which is active against the isolated organism can prevent this treatment failure to a certain extent. Obesity and diabetes were found to be predictors of antibiotic treatment failure in the skin and soft tissue infection. These risk factors should be considered while treating a patient for skin and soft tissue infection. The continuous monitoring of prescription and drug use pattern studies helps in identifying the problems involved in therapeutic decision-making and promotes rational prescribing.

\section{ACKNOWLEDGEMENT}

We are grateful to our Principal, Dr. A. P. Basavarajappa and HOD, Dr. J. Thimmasetty, and faculties of the Pharmacy Practice Department, Bapuji Pharmacy College for their continuous support and encouragement. It is a genuine pleasure to express our deep sense of thanks and sincere gratitude to our guide, Dr. Nazish Fathima, Asst. Professor, Department of Pharmacy Practice for her supervision, advice, patience, motivation, and enthusiasm.

\section{FUNDING}

Nil

\section{AUTHORS CONTRIBUTIONS}

All the authors have contributed equally.

\section{CONFLICT OF INTERESTS}

The authors declared that they have no conflict of interest.

\section{REFERENCES}

1. Chahine EB, Sucher AJ. Skin and soft tissue infections. PSAP; 2015. p. 1-27.

2. Conway EL, Sellick JA, Kurtzhalts K, Mergenhagen KA. Obesity and heart failure as predictors of failure in outpatient skin and soft tissue infections. Antimicrob Agents Chemother 2017;61:e02389-16.

3. Matthews P, Alpert M, Rahav G, Rill D, Zito E, Gardiner D, et al. A randomized trial of tigecycline versus ampicillin-sulbactam or amoxicillin-clavulanate for the treatment of complicated skin and skin structure infections. BMC Infect Dis 2012;12:297.

4. Brian K Alldredge, Mary Anne Koda Kimble, Lloyd Y Young. Applied therapeutics: the clinical use of drugs. $10^{\text {th }} \mathrm{Ed}$. Philadelphia: Wolters Kluwer/Lippincott Williams and Wilkins. Traumatic skin and soft tissue infections; 2013. p. 1662.

5. Cieri B, Conway EL, Sellick JA, Mergenhagen KA. Identification of risk factors for failure in patients with skin and soft tissue infections. Am J Emerg Med 2019;1:48-52.

6. Jaaskelainen IH, Hagberg L, Forsblom E, Jarvinen A. Factors associated with time to clinical stability in complicated skin and skin structure infections. Clin Microbiol Infect 2017;23:674-e1.

7. Garau J, Ostermann H, Medina J, Avila M, McBride K, Blasi F, et al. Current management of patients hospitalized with complicated skin and soft tissue infections across Europe (2010-2011): assessment of clinical practice patterns and real life effectiveness of antibiotics from the REACH study. Clin Microbiol Infect 2013:E377-85. https://doi.org/10.1111/1469-0691.12235

8. Jaaskelainen IH, Hagberg L, From J, Schyman T, Lehtola L, Jarvinen A. Treatment of complicated skin and skin structure infections in areas with low incidence of antibiotic resistance-a retrospective population-based study from Finland and sweden. Clin Microbiol Infect 2016;22:383-e1. 
9. Lipsky BA, Moran GJ, Napolitano LM, Vo L, Nicholson S, Kim M A prospective, multicenter, observational study of complicated skin and soft tissue infections in hospitalized patients: clinical characteristics, medical treatment, and outcomes. BMC Infect Dis 2012;12:227.

10. Yadav K, Suh KN, Eagles D, MacIsaac J, Ritchie D, Bernick J, et al. Predictors of oral antibiotic treatment failure for non-purulent skin and soft tissue infections in the emergency department. Acad Emerg Med 2019;26:51-9.

11. Demoz GT, Kasahun GG, Hagazy K, Woldu G, Wahdey S, Tadesse $\mathrm{DB}$, et al. Prescribing pattern of antibiotics using WHO prescribing indicators among inpatients in ethiopia: a need for antibiotic stewardship program. Infect Drug Resist 2020;13:2783-94. 